\title{
Blanching of papaya: effect on osmotic dehydration and characterization of the fruit invertase
}

\author{
Carolina Castilho Garcia ${ }^{1^{*}}$ (1) Fabio Shindi Uchidate ${ }^{2}$ Keila de Souza Silva $^{3}$ (1) \\ Luiz Gustavo Covizzi ${ }^{4}$ (D) Maria Aparecida Mauro ${ }^{2}$ (D)
}

${ }^{1}$ Universidade Tecnológica Federal do Paraná (UTFPR), Campus Medianeira, Departamento Acadêmico de Alimentos, 85884-000, Medianeira,
PR, Brasil. E-mail: carolinacgarcia@utfpr.edu.br. "Corresponding author.
${ }^{2}$ Universidade Estadual Paulista (UNESP), Instituto de Biociências, Letras e Ciências Exatas (IBILCE), Departamento de Engenharia e
Tecnologia de Alimentos, São José do Rio Preto, SP, Brasil..
${ }^{3}$ Universidade Estadual de Maringá (UEM), Campus Umuarama, Departamento de Tecnologia, Umuarama, PR, Brasil..
${ }^{4}$ Universidade Federal do Paraná (UFPR), Curitiba, PR, Brasil..

ABSTRACT: This research evaluated the influence of blanching on osmotic dehydration in sucrose solutions of papaya of Formosa cultivar. The characterization of invertase present in the fruits was also done. Blanching possibly caused damages to the cellular structure resulting in higher water loss, sugar gain and, thus, effective diffusion coefficients than fresh papayas during osmotic dehydration. The invertase extracted from papaya pulp presented optimum temperature of $45^{\circ} \mathrm{C}$ and optimum $\mathrm{pH}$ of 4.8. Considering the low production cost of papaya and the invertase characteristics, the fruit shows to be a potential source for the referred enzyme extraction.

Key words: Carica papaya L., diffusion coefficient, plant invertase, sugar composition.

Branqueamento de mamão: efeito na desidratação osmótica e caracterização da invertase da fruta

RESUMO: $O$ objetivo desse trabalho foi avaliar a influência do branqueamento na desidratação osmótica de mamão Formosa em soluções de sacarose. A caracterização da invertase presente nos frutos também foi realizada. O branqueamento possivelmente danificou a estrutura celular do vegetal resultando em maior perda de água, ganho de açúcar e, consequentemente, maior coeficiente de difusão do que os mamões frescos após a desidratação osmótica. A invertase extraída da polpa do mamão apresentou temperatura ótima de $45{ }^{\circ} \mathrm{C}$ e pH ótimo de 4.8. Considerando o baixo custo de produção do mamão e as características da invertase, essa fruta apresenta-se como potencial fonte de extração da enzima.

Palavras-chave: Carica papaya L., coeficiente de difusão, invertase vegetal, composição de açúcares.

\section{INTRODUCTION}

Papaya is a typical fruit of tropical regions presenting high amounts of vitamin $\mathrm{C}$ and mineral salts. The fruit does not present high pro-vitamin A activity; however, because it has long periods of crop and low cost of production, it becomes an important source of carotenoids (RODRIGUEZ-AMAYA, 1996).

In Brazil, losses of fruits and vegetables in harvest and post-harvest are great, achieving 30\% of the crop (SANTOS et al., 2020). Because of that, processing the fruit could represent an alternative to minimize these losses, adding value to the final product.

Osmotic dehydration (OD) is a process based on water removal from a product by its immersion in a hypertonic solution. During the process, solutes gain from the solution to the food and loss of some intracellular constituents with low molecular weight from the food to the solution is verified. Result of these transfers is a decrease on moisture content with a simultaneous increase on solids, besides changes on chemical composition of the dehydrated food (FERNANDES et al., 2006).

An advantageous of this minimal process is the possibility of modifying food formulation by incorporating different solutes in the porous structure of fruits and vegetables. Desirable effects in maintenance of tissue firmness were verified adding calcium to osmotic solutions (HEREDIA et al., 2007; RODRIGUES et al. 2003), since calcium ions can 
bind to the pectin present in the cellular wall and middle lamella reinforcing their structural integrity (PEREIRA et al., 2009; ALZAMORA et al., 1997).

Blanching is widely used for minimally processed food preparation aiming enzymatic inactivation, microorganisms destruction or injury to reduce initial microbial load of the food or awareness of the survivor microorganisms to posterior procedures (ALZAMORA et al., 1997). The great inconvenient of thermal treatment is the structural damage to the food resulting in its softening (SILVA et al., 2011; KOWALSKA et al., 2008; PAREDES ESCOBAR et al., 2007; ALZAMORA et al., 1997). When applied prior to drying or another treatment, researchers verified higher dehydration rates and/or reduced time of process (KOWALSKA et al., 2008; PAREDES ESCOBAR et al., 2007).

Invertase ( $\beta$-fructofuranosidase) is the enzyme that catalysis enzymatic hydrolysis of sucrose in equal proportions of glucose and fructose (GUIMARÃES et al., 2007). Traditionally this enzyme is obtained by the lysis of fungi cells such as Saccharomyces cerevisiae, Saccharomyces carlsbergenses and Aspergillus ochraceus (GUIMARÃES et al., 2007; ROMERO-GÓMEZ et al., 2000). CHAN \& KWOK (1975) verified that invertase activity in papayas of Solo cultivar was $0.821 \mathrm{U} \mathrm{mg}^{-1}$ of protein and that if the enzyme was not inactivated, half of the original sucrose in the fruits would be lost in $2.66 \mathrm{~min}$.

As enzyme activity can affect the mass transfer during OD, the objectives of this research were to evaluate the effect of blanching on OD kinetics of papaya of Formosa cultivar, characterizing the invertase present in papaya, regarding its stability, optimum operating $\mathrm{pH}$ and temperature and their kinetics parameters.

\section{MATERIALS AND METHODS}

\section{Samples preparation}

Papaya of Formosa cultivar from São Paulo State (Brazil) were purchased at São José do Rio Preto Supplying Center (CEAGESP - São José do Rio Preto, São Paulo, Brazil). Ripe fruits with orange peels weighting around $1.6 \mathrm{~kg}$ were used in the experiments.

Papayas were longitudinally cut in four pieces, peels and seeds were removed, and each portion was sectioned in cylinders of $3.6 \mathrm{~cm}$ of internal diameter with a manual cutter. These pieces were cut in slices with $1.0 \mathrm{~cm}$ of thickness. Samples were kept and mixed in a plastic bag from where the slices to be used in the experiments were randomly removed. These samples were used immediately after cutting procedure, which took about $1 \mathrm{~h}$.

For the enzymatic assays, two ripe fruits with orange peels weighting about $0.950 \mathrm{~g}$ were used. fruits were cut longitudinally in four pieces and two opposites sections of each one were taken to be used in the experiments. They were crushed and $100 \mathrm{~g}$ of pulp were used to extract the enzyme.

Soluble solids content and total solids of the pulp fruits were measured at each experiment.

\section{Blanching and osmotic dehydration}

Papaya slices were put in a stainless basket and dipped in boiling water $\left(98.3{ }^{\circ} \mathrm{C}\right.$ at São José do Rio Preto - SP - Brazil) for $2 \mathrm{~min}$. After this time, the samples were cooled in tap water for $1 \mathrm{~min}$.

Osmotic solutions were prepared with commercial sucrose (refined sugar) purchased in a local market, food grade calcium lactate pentahydrate in powder form from PURAC Synthesis - Brazil ( $1 \% \mathrm{w} / \mathrm{w}$ concentration), food grade $\mathrm{L}(+)$-lactic acid in $85 \%$ solution from PURAC Synthesis - Brazil (concentration of $0.1 \mathrm{M}$ ) and distilled water.

The OD experiments of fresh and blanched fruits were conducted in $40 \%, 50 \%$ and $60 \% \mathrm{w} / \mathrm{w}$ sucrose aqueous solutions with $1 \% \mathrm{w} / \mathrm{w}$ of calcium lactate and $0.1 \mathrm{M}$ of lactic acid. Processing times were $30,60,120,240$ and $360 \mathrm{~min}$.

OD experiments were conducted into a stainless steel vat with an external jacket for water circulation at $27{ }^{\circ} \mathrm{C}$. Osmotic solutions were continuously stirred using a $1.6 \mathrm{~kW}$ mechanical stirrer (Marconi, model MA-261 - Brazil) with a $10 \mathrm{~cm}$ diameter propeller and rotation of $1000 \mathrm{rpm}$. The ratio between sample and solution mass were at least 1:10.

Equilibrium experiments were conducted with fresh and blanched cylindrical slices of $4 \mathrm{~mm}$ thickness, immersed in the solutions, in flasks kept in a BOD incubator at $27^{\circ} \mathrm{C}$, on a platform with orbital agitation of $117.5 \mathrm{rpm}$, until the equilibrium was reached (about $48 \mathrm{~h}$ ). The rate between sample and solution mass was 1:10.

After osmotic treatments, samples were removed from the solutions, washed with distilled water for $10 \mathrm{~s}$ and dried on absorbing paper.

Total solids, reducing and total sugar contents were determined before and after process.

\section{Calculations}

Water and sucrose contents during OD were considered for diffusivities determination. However, for the fresh samples, as sucrose was not detected because it was enzymatically hydrolyzed 
to reducing sugars by invertase, the variation of the reducing sugars content during OD was used to calculate sucrose diffusion. For the blanched fruits, sucrose content was used.

The effective diffusion coefficients of water and sugar (sucrose/reducing sugar, $D_{k}$ ) in papaya slices was calculated by Fick's second law applied to an infinite slab (Equation 1). The analytical solutions in terms of the mean water or sugar contents in the slice at time t of OD, $\bar{w}_{k}(t)$, is (CRANK, 1975):

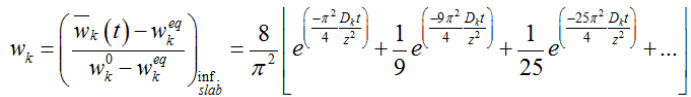

in which $k$ represents the species: $w$ is the water, $s c$ is sucrose and $r s$ is reducing sugar; superscript $e q$ indicates equilibrium; superscript 0 indicates initial (at $t=0) ; w_{k}$ represents mass fraction of the specie; $\bar{w}$ is the average content of the specie at time $t ; D_{k}$ is the effective diffusion coefficient of the specie, in $\mathrm{m}^{2}$ $\mathrm{s}^{-1} ; z$ is the half initial thickness of the samples.

\section{Extraction of invertase from papaya and enzymatic} assays

The activity of invertase was assessed in the papaya fruits because sucrose was not detected in non-blanched samples during OD process or in crushed fresh fruit after a few minutes. Thus, independent assays were carried out to characterize the invertase enzyme in papaya.

Based on the methodology used by Chan \& Kwok (1975), $100 \mathrm{~g}$ of papaya pulp were homogenized and submitted to an extraction process using ketone at $4{ }^{\circ} \mathrm{C}$. It was obtained $4.35 \mathrm{~g}$ of dried extract (DE). Enzymatic extract was obtained shaking a solution of $0.5 \mathrm{~g}$ of DE in $100 \mathrm{~mL}$ of acetate buffer $\mathrm{pH} 5.0(0.01 \mathrm{M})$ during $20 \mathrm{~min}$. After this time the suspension was centrifuged at $800 \mathrm{rpm}$ for $15 \mathrm{~min}$ at $13^{\circ} \mathrm{C}$ and then filtered in glass wool.

Enzymatic assays were conducted with $150 \mu \mathrm{L}$ of acetate/phosphate buffer $0.2 \mathrm{M}, 100 \mu \mathrm{L}$ of substrate (sucrose $1 \mathrm{M}$ ), enzyme and distilled water completing a final volume of $500 \mu \mathrm{L}$. The reducing sugars were determined using Somogy-Nelson method. To determine optimum $\mathrm{pH}$ the range of 3.0-8.0 was analyzed. To find optimum operating temperature the range of $30-65{ }^{\circ} \mathrm{C}$ was studied. Michaelis and Menten's kinetic parameters, $K_{m}$ and $V_{m}$, were estimated from Lineweaver-Bulk plots in the range of $0.03-0.4 \mu \mathrm{M}$ of sucrose concentration.

\section{Analytical methodologies}

Total solid contents of fresh, blanched, and osmotically dehydrated fruits were determined in triplicate in a vacuum oven at $60^{\circ} \mathrm{C}, 10 \mathrm{kPa}$, until constant weight. Total and reducing sugars of fresh, blanched, and osmotically dehydrated samples were determined in replicate by redox titration (WILLIAM, 1970).

\section{Statistical analysis and fitting}

Results were statistically analyzed by an Analysis of Variance (ANOVA) and Tukey test in a 5\% significance level, using Excel 2007 (Microsoft USA). Effective diffusion coefficients were calculated according to equation 1 using experimental data by minimizing the squares of the deviations between predicted and observed values, with the aid of a statistic software. The fitting efficiency was evaluated by the correlation coefficient $R^{2}$ and the mean relative error root square $(R R M S)$; the latter according to Equation 2.

$$
\operatorname{RRMS}(\%)=100\left\{\frac{1}{N} \sum_{n=1}^{N}\left[\frac{\left(x^{\text {calc }}-x^{\exp }\right)}{x^{\exp }}\right]\right\}^{1 / 2}
$$

where $x_{\text {calc }}$ represents water or sugar contents calculated according to Equation 1; $x_{\text {exp }}$ is the observed value; $N$ represents the number of observations.

\section{RESULTS AND DISCUSSION}

As can be seen in tables 1, 2 and 3, OD experiments showed that blanching resulted in decrease of total solids $(9.33 \pm 0.01 \mathrm{~kg} / 100 \mathrm{~kg})$ of papaya samples comparing to the respective fresh fruits (approximately $11.0 \mathrm{~kg} / 100 \mathrm{~kg}$ ), due to losses of soluble solids during thermal treatment. This lost was reflected in the reducing sugars content which was higher in fresh (approximately $7.5 \mathrm{~kg} / 100 \mathrm{~kg}$ ) than in blanched fruits $(4.14 \pm 0.05 \mathrm{~kg} / 100 \mathrm{~kg})$.

The total solids content of fresh fruits is presented in tables 1, 2 and 3 when the time of OD is equal zero $(0)$. The absence of sucrose is explained by the enzymatic activity of invertase. The total solids content of blanched fresh fruits is also shown at the initial instant in the same Tables.

As noticed by KOWALSKA et al. (2008) and SILVA et al. (2011) for pumpkins, thermal treatment possibly damaged the cellular tissue of papayas, since, for the same process time, higher solute gain was observed for the blanched fruits in relation to the fresh samples independently of solution concentration. Sugar gain of fresh samples (reducing sugar) increased when increasing dewatering time and low dependence with solution concentration was observed, as can be seen in tables 1, 2 and 3. Sucrose gain of blanched fruits presented low dependence with solution concentration for short OD times and 
Table 1 - Mean \pm SD of total solids $\left(w_{t s}\right)$, sucrose $\left(w_{s c}\right)$ and reducing sugars $\left(w_{r s}\right)$ contents in unblanched and blanched papaya slices during OD in $40 \% \mathrm{w} / \mathrm{w}$ sucrose solution with $1 \% \mathrm{w} / \mathrm{w}$ of calcium lactate and $0.1 \mathrm{M}$ of lactic acid.

\begin{tabular}{|c|c|c|c|}
\hline Time (min) & $w_{t s}(\mathrm{~kg} / 100 \mathrm{~kg})$ & $w_{s c}(\mathrm{~kg} / 100 \mathrm{~kg})$ & $w_{r s}(\mathrm{~kg} / 100 \mathrm{~kg})$ \\
\hline \multicolumn{4}{|c|}{ 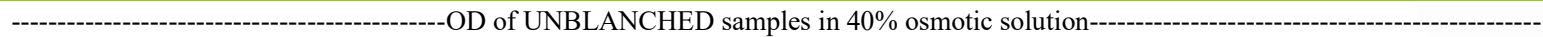 } \\
\hline 0 & $12.12 \pm 0.34$ & ND & $8.24 \pm 0.68$ \\
\hline 30 & $16.49 \pm 0.90$ & ND & $11.64 \pm 0.72$ \\
\hline 60 & $18.11 \pm 0.87$ & ND & $13.01 \pm 1.27$ \\
\hline 120 & $20.10 \pm 0.28$ & ND & $15.84 \pm 0.26$ \\
\hline 240 & $23.25 \pm 3.45$ & ND & $19.23 \pm 0.06$ \\
\hline 360 & $28.25 \pm 0.12$ & ND & $21.90 \pm 0.38$ \\
\hline \multicolumn{4}{|c|}{ - } \\
\hline 0 & $9.33 \pm 0.01$ & $2.61 \pm 0.02$ & $4.14 \pm 0.05$ \\
\hline 30 & $16.30 \pm 0.03$ & $9.47 \pm 0.01$ & $3.53 \pm 0.02$ \\
\hline 60 & $19.66 \pm 0.12$ & $12.61 \pm 0.03$ & $3.35 \pm 0.02$ \\
\hline 120 & $23.95 \pm 0.06$ & $17.46 \pm 0.07$ & $2.88 \pm 0.01$ \\
\hline 240 & $29.59 \pm 0.05$ & $24.33 \pm 0.07$ & $1.54 \pm 0.00$ \\
\hline 360 & $34.14 \pm 0.05$ & $28.43 \pm 0.02$ & $2.02 \pm 0.02$ \\
\hline
\end{tabular}

ND: Not detected.

increasing solution concentration increased sucrose gain of these samples for dewatering times up to 120 min (Tables 1, 2 and 3).

Tables 1, 2 and 3 shows that for the fresh papayas, after equal process time, the higher the osmotic concentration, the higher the total solid and reducing sugar contents measured in the dehydrated samples in sucrose solutions at $40 \%$ and $50 \%$. However, minor changes were observed for fresh papayas dehydrated in solutions at 50\% and $60 \%$. For the blanched fruits, the higher the osmotic concentration, the higher were the total solid in the dehydrated samples after the same time of OD. Considering sucrose content, few differences

Table 2 - Mean \pm SD of total solids $\left(w_{t s}\right)$, sucrose $\left(w_{s c}\right)$ and reducing sugars $\left(w_{r s}\right)$ contents in unblanched and blanched papaya slices during OD in $50 \% \mathrm{w} / \mathrm{w}$ sucrose solution with $1 \% \mathrm{w} / \mathrm{w}$ of calcium lactate and $0.1 \mathrm{M}$ of lactic acid.

\begin{tabular}{|c|c|c|c|}
\hline Time (min) & $w_{t s}(\mathrm{~kg} / 100 \mathrm{~kg})$ & $w_{s c}(\mathrm{~kg} / 100 \mathrm{~kg})$ & $w_{r s}(\mathrm{~kg} / 100 \mathrm{~kg})$ \\
\hline \multicolumn{4}{|c|}{ 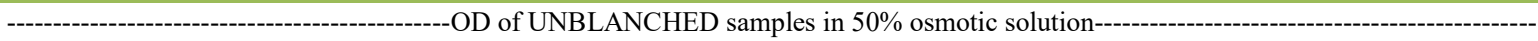 } \\
\hline 0 & $9.82 \pm 1.43$ & ND & $7.06 \pm 1.47$ \\
\hline 30 & $14.78 \pm 0.55$ & ND & $11.72 \pm 0.39$ \\
\hline 60 & $16.21 \pm 0.21$ & ND & $12.49 \pm 0.67$ \\
\hline 120 & $19.51 \pm 0.94$ & ND & $15.78 \pm 0.16$ \\
\hline 240 & $25.13 \pm 0.35$ & ND & $20.12 \pm 1.21$ \\
\hline 360 & $30.00 \pm 0.15$ & ND & $24.71 \pm 2.18$ \\
\hline \multicolumn{4}{|c|}{ - } \\
\hline 0 & $9.33 \pm 0.01$ & $2.60 \pm 0.02$ & $4.15 \pm 0.04$ \\
\hline 30 & $18.61 \pm 0.02$ & $11.64 \pm 0.05$ & $3.50 \pm 0.00$ \\
\hline 60 & $21.60 \pm 0.01$ & $14.58 \pm 0.01$ & $3.16 \pm 0.02$ \\
\hline 120 & $28.48 \pm 0.01$ & $21.80 \pm 0.00$ & $3.18 \pm 0.00$ \\
\hline 240 & $34.08 \pm 0.01$ & $27.17 \pm 0.74$ & $2.57 \pm 0.00$ \\
\hline 360 & $39.04 \pm 0.03$ & $31.10 \pm 0.74$ & $2.21 \pm 0.10$ \\
\hline
\end{tabular}

ND: Not detected.

Ciência Rural, v.51, n.9, 2021. 
Table 3 - Mean \pm SD of total solids $\left(w_{t s}\right)$, sucrose $\left(w_{s c}\right)$ and reducing sugars $\left(w_{r s}\right)$ contents in unblanched and blanched papaya slices during OD in $60 \% \mathrm{w} / \mathrm{w}$ sucrose solution with $1 \% \mathrm{w} / \mathrm{w}$ of calcium lactate and $0.1 \mathrm{M}$ of lactic acid.

\begin{tabular}{|c|c|c|c|}
\hline Time (min) & $w_{t s}(\mathrm{~kg} / 100 \mathrm{~kg})$ & $w_{s c}(\mathrm{~kg} / 100 \mathrm{~kg})$ & $w_{r s}(\mathrm{~kg} / 100 \mathrm{~kg})$ \\
\hline \multicolumn{4}{|c|}{ - } \\
\hline 0 & $10.01 \pm 0.04$ & ND & $7.18 \pm 0.04$ \\
\hline 30 & $14.17 \pm 0.06$ & ND & $11.23 \pm 0.04$ \\
\hline 60 & $16.88 \pm 0.02$ & ND & $13.56 \pm 0.06$ \\
\hline 120 & $19.48 \pm 0.02$ & ND & $15.38 \pm 0.02$ \\
\hline 240 & $25.39 \pm 0.01$ & ND & $20.99 \pm 0.63$ \\
\hline 360 & $31.23 \pm 0.01$ & ND & $26.86 \pm 0.13$ \\
\hline \multicolumn{4}{|c|}{ - } \\
\hline 0 & $9.33 \pm 0.01$ & $2.53 \pm 0.12$ & $4.14 \pm 0.05$ \\
\hline 30 & $17.70 \pm 0.12$ & $10.51 \pm 0.14$ & $3.66 \pm 0.00$ \\
\hline 60 & $22.04 \pm 0.05$ & $13.70 \pm 0.26$ & $3.78 \pm 0.01$ \\
\hline 120 & $29.48 \pm 0.04$ & $20.09 \pm 0.25$ & $3.57 \pm 0.04$ \\
\hline 240 & $41.47 \pm 0.01$ & $30.44 \pm 0.01$ & $3.35 \pm 0.04$ \\
\hline 360 & $46.60 \pm 0.00$ & $36.12 \pm 0.00$ & $2.93 \pm 0.01$ \\
\hline
\end{tabular}

ND: Not detected.

between blanched samples dehydrated in $50 \%$ and $60 \%$ solutions were observed.

Sucrose was not detected in the fresh fruits as a result of the fast sugar inversion that occurred during samples manipulation. In fact, as can be seen in tables 1, 2 and 3, during OD of fresh samples, independently of process time, sucrose was not detected. Conversely, reducing sugars average contents of osmo-treated fresh slices increased with process time in relation to the initial value corroborating the hypothesis of the fast inversion of these sugars.

Regarding OD of blanched papayas, it was verified the increase on sucrose content with time due to solids incorporation. Reducing sugars content of blanched samples remained practically constant during the first hour of OD. For longer dehydration times, slight decrease of reducing sugars was noticed, which were probably transferred to the dehydrating solution (Tables 1, 2 and 3).

Comparing OD of fresh and blanched samples, it could be concluded that papaya of Formosa cultivar presented high activity of invertase enzyme which is responsible for sucrose hydrolysis in glucose and fructose. This fact explained the failure to measure the sucrose contents of osmo-dehydrated fresh fruits and the increases in their reducing sugar contents over dehydration. Blanching inactivated the enzyme, so sucrose contents of blanched fruits increased during OD. The invertase present in papaya of Formosa cultivar was characterized.
The effective diffusion coefficients of fresh and blanched papayas submitted to OD in $40 \%$, $50 \%$ and $60 \% \mathrm{w} / \mathrm{w}$ sucrose aqueous solutions with calcium lactate $(1 \% \mathrm{w} / \mathrm{w})$ and lactic acid $(0.1 \mathrm{M})$ are presented in table 4 . For the fresh fruits, it was calculated the effective diffusion coefficients of water and reducing sugars and, for the blanched slices, the coefficients of water and sucrose.

As for pure sucrose solutions, for each treatment time, the diffusion coefficients decreased when the concentration of the osmotic solution increased, except for the water diffusivities of blanched samples osmo-treated at $50 \%$ and $60 \%$ solutions. It was expected that the last samples presented lower diffusivities, but, probably due to great tissue damages, enhancing diffusion processes, they resulted higher than the slices dehydrated in the solution at $50 \%$.

Diffusion coefficients of blanched fruits were higher than the fresh ones. These results are in agreement with the hypothesis that thermal treatment caused cellular tissue damages leading to loss of selective permeability of the plasmalemma and thus facilitating diffusive process.

The effective diffusion coefficients calculated for papaya of Formosa cultivar were lower than the ones calculated for pumpkins by SILVA et al. (2011) and for carrots by PAREDES ESCOBAR et al. (2007), but within the range reported for pumpkins by KOWALSKA et al. (2008). 
Table 4 - Effective diffusion coefficients of water $\left(D_{w} \times 10^{10}\right.$, in $\left.\mathrm{m}^{2} \mathrm{~s}^{-1}\right)$ and sugar $\left(D_{s} \times 10^{10}\right.$, in $\left.\mathrm{m}^{2} \mathrm{~s}^{-1}\right)$ during OD of fresh and blanched papayas of Formosa cultivar, calculated according to equation 1.

\begin{tabular}{|c|c|c|c|c|c|c|c|}
\hline Sample & Osmotic solution, $(\% \mathrm{w} / \mathrm{w})$ & Water & & & Sugar & & \\
\hline & & $D_{w}$ & $R R M S(\%)$ & $R^{2}$ & $D_{s}$ & $R R M S(\%)$ & $R^{2}$ \\
\hline Fresh & \multirow{2}{*}{40} & 2.10 & 5.90 & 0.958 & 2.92 & 3.72 & 0.987 \\
\hline Blanched & & 5.32 & 5.67 & 0.995 & 4.35 & 3.49 & 0.994 \\
\hline Fresh & \multirow{2}{*}{50} & 1.92 & 4.67 & 0.970 & 1.99 & 5.53 & 0.962 \\
\hline Blanched & & 3.94 & 3.22 & 0.993 & 4.27 & 4.91 & 0.989 \\
\hline Fresh & \multirow{2}{*}{60} & 1.45 & 4.79 & 0.960 & 1.94 & 7.25 & 0.953 \\
\hline Blanched & & 4.51 & 8.82 & 0.978 & 3.15 & 5.17 & 0.981 \\
\hline
\end{tabular}

$s$ is the reducing sugars for the fresh samples $\left(D_{r s}\right)$ and sucrose for the blanched fruits $\left(D_{s c}\right)$.

To characterize the invertase present in papaya, independent experiments were carried out. The fruit pulp used in these analyses had $14.78 \pm 0.005$ of total solids content and $14.1 \%$ of soluble solids content. The optimum temperature of the enzyme was $45{ }^{\circ} \mathrm{C}$ and the optimum $\mathrm{pH}$ was 4.8 . These values were close to the ones found for strawberries and Japanese pear (VIBERG \& SJÖHOLM, 1998; HASHIZUME et al., 2003). The fungal enzymes usually used in inverted sugar production present optimum $\mathrm{pH}$ around 4.5 and optimum temperature ranging from $55-60{ }^{\circ} \mathrm{C}$ (GUIMARÃES et al., 2007; ROMERO-GÓMEZ et al., 2000).

Increasing $\mathrm{pH}$ values up to 6.5 , enzymatic activity decreased 75\%; pH values below 3.5 decreased invertase activity to $35 \%$ of its original value. Invertase contained in papayas of Formosa cultivar presented activity up to $30 \%$ when kept at 35 or $40{ }^{\circ} \mathrm{C}$ for until $4 \mathrm{~h}$. At $55^{\circ} \mathrm{C}$ its activity decreased $75 \%$ after $15 \mathrm{~min}$. Enzymes presenting high optimum temperature and thermal stability are interesting for biotechnology application in many industries (GUIMARÃES et al., 2007).

The kinetic parameters of papaya invertase was obtained according to Lineweaver-Burk model and were: $K_{m}=66.31 \mathrm{mM}$ and $V_{m}=0.896 \mu \mathrm{M} \cdot \mathrm{min}^{-1}$. The value of Michaellis-Menten constant $\left(K_{m}\right)$ of the invertase extracted from papaya of Formosa cultivar was higher than the reported for bananas $(2.7 \mathrm{mM})$, mango $(5.0$ to $0.9 \mathrm{mM})$ and Japanese pear (3.33 to $4.58 \mathrm{mM}$ ). The fungal invertases present $K_{m}$ ranging from 2 to $7 \mathrm{mM}$ (GUIMARÃES et al., 2007; HASHIZUME et al., 2003; ROMERO-GÓMEZ et al., 2000).

Briefly, Michaellis-Menten constant indicated an apparent affinity of the enzyme by the substrate: higher its value, lower affinity. Therefore, it was verified that the invertase of papaya presented lower affinity to sucrose than the enzymes extracted from fungi and another fruits (GUIMARÃES et al., 2007; HASHIZUME et al., 2003; ROMEROGÓMEZ et al., 2000).

The velocity of hydrolysis $\left(V_{m}\right)$ is proportional to the concentration of the sucrose-invertase compound, and to the fraction of the invertase which is combined with sucrose. Therefore, when the sucrose concentration is such that the velocity is at its maximum, then this proportion is equal 1 (NELSON \& LARSON, 1927). Papaya of Formosa cultivar presented high invertase concentration since the $V_{m}$ value was almost 1 .

Considering the low production cost of the fruit and its great harvest and post-harvest losses and the enzyme characteristics, papaya of Formosa cultivar is presented as a potential source to invertase extraction.

\section{CONCLUSION}

Blanching of papaya damaged the cellular tissue since during OD process these samples presented higher water loss and sugar gain than the fresh fruits, in agreement with the diffusion coefficients which were higher for the blanched fruits than the fresh ones.

Invertase was detected in papaya of Formosa cultivar. Regarding the low cost of fruit production and the invertase characteristics, papaya of Formosa cultivar is presented as a potential source for invertase extraction.

\section{ACKNOWLEDGEMENTS}

Authors are grateful to Coordenação de Aperfeiçoamento de Pessoal de Nível Superior (CAPES) for the scholarship, to Fundação de Amparo à Pesquisa do Estado de São 
Paulo (FAPESP) for the financial support (Proc 07/07586-0 and Proc 09/00519-0) and to PURAC Synthesis - Brazil.

\section{DECLARATION OF CONFLICT OF INTEREST}

The authors declare no conflict of interest. The founding sponsors had no role in the design of the study; in the collection, analyses, or interpretation of data; in the writing of the manuscript, and in the decision to publish the results.

\section{AUTHORS' CONTRIBUTIONS}

All authors contributed equally for the conception and writing of the manuscript. All authors critically revised the manuscript and approved of the final version.

\section{REFERENCES}

ALZAMORA, S. M. et al. In: Food Engineering 2000. Structural changes in the minimal processing of fruits: some effects of blanching and sugar impregnation. New York: Chapman and Hall, 1997, p.117-139.

CHAN JR., H. T.; KWOK, S. C. M. Importance of enzyme inactivation prior to extraction of sugars from papaya. Journal of Food Science, v.40, p.770-771, 1975. Available from: $<$ https:// doi.org/10.1111/j.1365-2621.1975.tb00552.x>. Accessed: Jun. 09, 2020. doi: 10.1111/j.1365-2621.1975.tb00552.x.

CRANK, J. The Mathematics of Diffusion. Oxford, UK Clarendon Press., 1975, 414p.

FERNANDES, F. A. N. et al. Optimization of osmotic dehydration of papaya followed by air-drying. Food Research International, v.39, p.492-498, 2006. Available from: $<$ https://doi.org/10.1016/j. foodres.2005.10.004>. Accessed: Jun. 09, 2020. doi: 10.1016/j. foodres.2005.10.004.

GUIMARÃES, L. H. S. et al. Production and characterization of a thermostable extracellular $\beta$-d-fructofuranosidase produced by Aspergillus ochraceus with agroindustrial residues as carbon sources. Enzyme and Microbial Technology, v.42, p.52-57, 2007. Available from: <https://doi.org/10.1016/j. enzmictec.2007.07.021>. Accessed: Jun. 09, 2020. doi: 10.1016/j. enzmictec.2007.07.021.

HASHIZUME, $H$. et al. Purification and characterization of two soluble acid invertase isozymes from Japanese pear fruit. Phytochemistry, v.63, p.125-129, 2003. Available from: <https:// doi.org/10.1016/S0031-9422(03)00107-9>. Accessed: Jun. 09, 2020. doi: 10.1016/S0031-9422(03)00107-9.

HEREDIA, A. et al. Drying of cherry tomato by a combination of different dehydration techniques. Comparison of kinetics and other related properties. Journal of Food Engineering, v.80, n.1, p.111-118, 2007. Available from: <https://doi.org/10.1016/j. jfoodeng.2006.04.056>. Accessed: Jun. 09, 2020. doi: 10.1016/j. jfoodeng.2006.04.056
KOWALSKA, A. et al. The effect of blanching and freezing on osmotic dehydration of pumpkin. Journal of Food Engineering, v.86, p.30-38, 2008. Available from: <https://doi.org/10.1016/j. jfoodeng.2007.09.006>. Accessed: Jun. 09, 2020. doi: 10.1016/j. jfoodeng.2007.09.006.

NELSON, J. M.; LARSON, H. W. Kinetics of invertase action. The Journal of Biological Chemistry, v.73, n.11, p.223-236, 1927. Available from: <https://www.jbc.org/content/73/1/223.short>. Accessed: Jun. 09, 2020. doi: 10.1016/S0021-9258(18)84308-3.

PAREDES ESCOBAR, M. et al. Effect of long-term storage and blanching pre-treatment on the osmotic dehydration kinetics of carrots (Daucus carota L. cv. Nerac). Journal of Food Engineering, v.81, p.313-317, 2007. Available from: $<$ https://doi. org/10.1016/j.jfoodeng.2006.11.005>. Accessed: Jun. 09, 2020. doi: 10.1016/j.jfoodeng.2006.11.005.

PEREIRA, L. M. et al. Microscopic features, mechanical and thermal properties of osmotically dehydrated guavas. LWT - Food Science and Technology, v.42, p.378-384, 2009. Available from: $<$ https://doi.org/10.1016/j.lwt.2008.06.002>. Accessed: Jun. 09, 2020. doi: 10.1016/j.lwt.2008.06.002.

RODRIGUES, A. C. C. et al. Rheological properties and colour evaluation of papaya during osmotic dehydration processing. Journal of Food Engineering, v.59, p.129-135, 2003. Available from: $\quad<$ https://doi.org/10.1016/S0260-8774(02)00442-9>. Accessed: Jun. 09, 2020. doi: 10.1016/S0260-8774(02)00442-9.

RODRIGUEZ-AMAYA, D. B. Assessment of the provitamin A contents of foods - the Brazilian experience. Journal of Food Composition and Analysis, v.3, p.196-229, 1996. Available from: $<$ https://doi.org/10.1006/jfca.1996.0028>. Accessed: Jun. 09, 2020. doi: 10.1006/jfca.1996.0028.

ROMERO-GÓMEZ, S. J. et al. Invertase production by Aspergillus niger in submerged and solid-state fermentation. Biotechology Letters, v.22, n.15, p.1255-1258, 2000. Available from: <https:// doi.org/10.1023/A:1005659217932>. Accessed: Jun. 09, 2020. doi: 10.1023/A:1005659217932.

SANTOS, F. S. dos et al. Post-harvest losses of fruits and vegetables in supply centers in Salvador, Brazil: Analysis of determinants, volumes and reduction strategies. Waste Management, v.101,p.161-170, 2020. Available from: <https://doi.org/10.1016/j.wasman.2019.10.007>. Accessed: Jun. 25, 2020. doi: 10.1016/j.wasman.2019.10.007.

SILVA, K. S. et al. Osmotic dehydration process for low temperature blanched pumpkin (Cucurbita moschata). Journal of Food Engineering, v.82, p.509-517, 2011. Available from: $<$ https://doi.org/10.1016/j.jfoodeng.2011.01.025>. Accessed: Jun. 09, 2020. doi: 10.1016/j.jfoodeng.2011.01.025.

VIBERG, U.; SJOHOLM, I. Sucrose inversion during osmotic pretreatment of strawberries. LWT - Food Science and Technology, v.31, p.546-551, 1998. Available from: <https://doi.org/10.1006/ fstl.1998.0412>. Accessed: Jun. 09, 2020. doi: 10.1006/fstl.1998.0412.

WILLIAM, H. Official Methods of Analysis, 11th ed. Arlington: Association of Official Analytical Chemists, AOAC, 1970. 